\title{
E-Democracy in Africa: Assessing Internet Use by Major Political Parties during Elections in Cameroon
}

\author{
Kingsley L. Ngange, Martin E-M. Elonge \\ Department of Journalism and Mass Communication, University of Buea, Buea, Cameroon \\ Email: kngange@yahoo.com
}

How to cite this paper: Ngange, K. L., \& Elonge, M. E-M. (2019). E-Democracy in Africa: Assessing Internet Use by Major Political Parties during Elections in Cameroon. Advances in Journalism and Communication, 7, 55-73.

https://doi.org/10.4236/ajc.2019.73004

Received: May 30, 2019

Accepted: August 9, 2019

Published: August 12, 2019

Copyright ( 2019 by author(s) and Scientific Research Publishing Inc. This work is licensed under the Creative Commons Attribution International License (CC BY 4.0).

http://creativecommons.org/licenses/by/4.0/

\begin{abstract}
The Internet provides important opportunities for interactions between candidates and voters as well as new arenas for voter-to-voter discussions and interaction before, during and even after an election. Growing concerns on the use of the Internet for political propaganda warrants an understanding of its preponderance on Cameroon's political communication landscape. This is done following the theoretical underpinnings of Uses and Gratifications theory (Katz \& Blumler, 1974) and Agenda Setting theory (McCombs \& Shaw, 1972). Through carefully selected approaches (mix research methods), this study content analyzes the websites of two major political parties in Cameroon: the Cameroon Peoples Democratic Movement (CPDM), which is the ruling party for the past 34 years and Social Democratic Front (SDF), as the leading opposition party for the past 29 years. It also surveys, through self-administered questionnaires, the effects of Internet use by these political parties on 100 academics and party supporters who participated as respondents in the study. The findings reveal that with the growth of Internet-mediated political communication in the country, political participation is on the increase with $77 \%$ of academics/party supporters attesting to their participation in online political discussions. This firmly supports evidence that political parties use the Internet to mobilize support (43\%) as well as set political agendas (18\%). The study concludes that as new media use keeps increasing in the political process in Cameroon, there will be a considerable drift from the use of "old media" in communicating political agendas. To achieve the full benefits of this shift, need exists for stakeholders, especially the government, to develop and implement adequate ICT policies. Looking at the present day impact of the Internet on human existence, especially on the political sphere, it is expedient that all those in this stratum of influence study and better understand the dynamics of this new form of communication. By
\end{abstract}


so doing, the incidence of unnecessary propaganda, capable of distorting every day existence, shall be reduced.

\section{Keywords}

New Media, Internet, E-Democracy, Political Communication

\section{Introduction}

The use of Information and Communication Technologies (ICTs) for political communication has grown to a wide and organized practice in the developed world; a situation yet to be experienced fully in developing nations. Describing the idealistic discussion on ICTs as one that subsumes tremendous impact, Tanjong (2006: p. 55) says "the reality in Africa is that the Internet is relatively new and it is just beginning to penetrate Africa". And for such reasons as limited resources to invest in the Internet comparatively to developed countries, the necessary benefits, like participatory democracy, remain an illusion to many (Tufte, Wildermuth, Hansen-Skovmoes, \& Mitullah, 2013).

The effects of human activities on communication and their concomitant advantages and disadvantages are nebulous and transient (Nwokeafor \& Langmia, 2010). To understand this, it behooves for the researchers to probe into the role of the "information elites" and the use of the Internet by political parties in Cameroon, within a context described as political marketing (Maarek, 1995) and political propaganda (Tanjong, 2006).

Norris (2001) holds that political communication is an interactive process in which politicians share information among themselves, in the news media and in the general public. Norris (ibid) attests this communication pattern functions downward from governing institutions toward citizens, horizontally in linkages among political actors and more, upward from public opinion toward powers that be.

In Africa, like the USA, colonial masters consolidated their rule on colonies through official publications in the press. The first newspapers in Africa were published in the early 1820's (Muluh, 2002). In the Gold Coast (Ghana) for instance, there were official publications like The Royal Gold Coast Gazette, Accra 1822. In Nigeria where press laws were not rigid, there was a fast growth of the press and the country had the highest number of newspapers registered in Sub-Saharan Africa (21 in all: 7 dallies, 13 weeklies and 1 monthly). Nigerians had learnt how to communicate using the mass media. Politicians like Dr. Nnamdi Azikiwe championed the course for independence with publications like: The West African Pilot, 1937. This nationalist paper did not only preach these ideas in Nigeria but extended to neighboring Cameroon (which was colonized by Britain and France).

Cameroonians engaged in the use of the written press to fight for their rights 
from both the colonial administration and their subversive brothers. The oldest indigenous political party, Union des Populations du Cameroun (UPC), in 1948 through its La Voix du people, a strongly worded, caustic and bitter-toned paper, was able to mobilize support against the moderates like Albert Mbidda and Ahmadou Ahidjo, whom they said were allies to the French colonial government. Other papers like La Verite, La Lumiere (1954-56) and Le Bamileke (1955) were all early papers in French Cameroon which were used for political propaganda. In British Cameroon, the press contributed to the formation of public opinion and making political leaders popular. Politicians and political parties in the English part of the country depended mainly on two major papers: Cameroons Champion and Cameroon Times to address their different political ideas. Cameroons Champions published on 21st Nov, 1960 propagated the ideas of Dr. Emmanuel Mbella Lifafa Endeley's Cameroon People's National Congress (CPNC) for integration with Nigeria. This was a view opposed by John NguFoncha's Party, backed by Cameroon Times of $9^{\text {th }}$ Dec, 1960 for reunification with French Cameroon. The Cameroon People's Democratic Movement (CPDM) of President Paul Biyacreated in 1985 has as communication tool L'Action newspaper while the SDF made use of the Socialist Chronicles (Nyamnjoh, 2005).

Communication patterns respond rapidly to the changes in society at every given point in time. Soriano (2013) argues that the effects of Internet on political change depend on the context and the ability of actors who use it. According to Maarek (1995), expansion in modern political marketing (propaganda) in the US is fostered by the rapid growth of mass media with regard to all other democratic countries. The most effective uses of new channels for political campaigns in the US are tied to President John Kennedy's use of television (1961) and President Barack Obama's use of the Internet (Web 2.0 tools) in the 2008 presidential elections (Miller, 2008). The present age has ushered a great deal of newness in communication tools and it is interesting to know how this new age communication drive has been exploited for political communication in Cameroon.

The contemporary media in Cameroon is a phenomenon strongly influenced by the pattern of the nation's past. Nyamnjoh (2005) says the relationship between the media and politics in Cameroon continues to alternate with each influencing the other. Multi-party politics was re-introduced in Cameroon in 1990 following Law No. No 90/056 on press freedom and the freedom of associations, after a single party system for 24 years (1966-1990). This paved the way for some 102 legalized political parties to be registered by August 1994 (Gwellem, 1996). The reforms in the Ministry of Posts and Telecommunications in 1998 also brought about great changes in the media landscape of the country. One of the early effects of the cell phone and Internet, as political weapons, was in June 2004 when they were used to spread rumours that President Paul Biya had died in Switzerland. Nyamnjoh (ibid) says the Cameroon government alleged that the rumour was inflamed by an online newspaper, the African Independent. 
With the increasing use of new tools for the dissemination of information and propaganda, many political parties in Cameroon have designed websites and blogs. This study content analyzes the websites of two major political parties: the Cameroon People's Democratic Movement (2011), which is the ruling party for the past 34 years and Social Democratic Front-SDF (2011), as the leading opposition party for the past 29 years. The research seeks to know the degree of use of the Internet by political parties in Cameroon and the effect it has had in recent times on the country's political heritage. The main objective is to see if these trends now migrating from the West to Africa have similar effects on the political process (Karan, Gimeno, \& Tandoc, 2009).

\section{Understanding the Language of Political Communication}

According to Graber (1981), politics is largely a word game. Politicians rise to power because they can talk persuasively to voters and political elites. Once in power, their daily activities are largely verbal-a system of sounds, words and patterns which are used to communicate thoughts and feelings. Rotunda (1986) says language should be viewed as the medium for the generation and perpetuation of political significant symbols. Political consciousness therefore, results from a largely symbolic interpretation of sociopolitical experience. The language of government in many ways is the dissemination of illusion and ambiguity ( $\mathrm{Da}$ vis, 1995). A successful politician will use rather specific linguistic devices that reinforce popular beliefs, attitudes and values (Maarek, 1995) to mask their propaganda. What makes language political is not the particular vocabulary or linguistic form but the substance of information the language conveys, the setting in which the interaction occurs and the explicit or implicit functions the language performs. Graber (1981) identifies five major functions of political language: information dissemination; agenda-setting; interpretation and linkage; projection for the future and the past; and action stimulation.

In all forms of communication, the communicators have at the back of their minds "action" to be taken by whoever is the target. In the 1930s, the Nazi used rallies "notably the annual party congress in Nuvemberg" organized by Hitler's minister of propaganda, Goebbels, for the purpose of political communication (Maarek, 1995: p. 96). This same technique was exploited by France's Far-right "Front National" party in the 1980s. There are many ways information is shared with the public in political messages. The most obvious, of course, is the sharing of explicit information about the state of polity. Such is vital to the public's understanding and support of the political system. This is especially true in democratic nations where the instruments and decision-making process of government officials are open to the public. The public, being sensitized to uses of language, can obtain "information" by what is not stated, how something is stated or when it is stated. An important function of political communication is to link people to past glories and reveal the future to cast out doubts and uncertainty in a world of ever increasing complexity. To say the least, political language must function to mobilize society and stimulate social action. Language serves as the 
stimulus, means or rationale for social action. Words can evoke, persuade, implore, command, label, praise and condemn. Opinions of individuals according to Berinsky (2004) have a role to play in the political atmosphere of any country. This brings to mind the public opinion theory and stimulates more the need for political participation. Public opinion is the embodiment of the consent of the governed indemocratic systems. Thomas Jefferson in 1787 (as cited McLeod, Pan, \& Rucinski, 1995) stated that public opinion, though sometimes may momentarily be led astray, is self-correcting and the only legitimate censor of government. Just like the technological and economic changes of the $18^{\text {th }}$ century came to bear on government policy by the voiceless, more so is it in this era $\left(21^{\text {st }}\right.$ century and beyond) where the advent of more sophisticated technologies-the convergent-Internet (Thorburn \& Jenkins 2003), have allowed for greater political participation by the governed (García, 2006; Hugh \& O'Sullivan, 1999).

In Cameroon, the government is making strides to operate properly as a result of the existence of public opinion. Though insufficient, the opinions of the citizens are heard directly or indirectly by the governing body. In today's world of technology, no matter how many barriers are put, people use different and sometimes unconventional methods to build their own infrastructure for dialogue and debate (Herbst, 1994). This has both positive and negative implications because communication represents the opportunity for stimulation and growth as well as the threat of external influence. Personal development is impossible without self-evaluation and reflection that comes from interaction and communication with others. If there have been any up risings in the Arab world today, it is largely due to many years of interaction and communication (which has become more advanced with the emergence of sophisticated media forms-the Internet, mobile phones, etc.) with the outside (Western) world. And as Jeffres (1986) argues, isolated nations and national cultures are less likely to develop far or be very creative without the stimulation that comes from consistent contact and communication with representatives of other nations and their cultures.

Politics as postulated by Nimmo (1978) is the authoritative allocation of political views. Through politics, individuals are able to express and find ways of ameliorating their social conditions in societies that are especially authoritarian. Politics like communication is a process and like communication, politics involves talk. Not talk in the narrow sense of the spoken word but in the more inclusive to mean all ways through which people exchange symbols which include: pictures, gestures, written words in the media and on the Internet. Political communication can be considered as political activity by virtue of its consequences (actual and potential) which regulate human conduct under conditions of conflict.

\section{Theorizing New Media (Internet) in Political Communication}

Chun \& Thomas (2006) say the term "new media" came into prominence in the mid-1990s and unlike its predecessor "multi-media", new media proved unac- 
commodating as it portrayed others as old or dead, converging and not multiplying and staying on even in times of great plurality. To them, describing something as "new" is to categorize, describe and prescribe it; while at the same time insist that it is wonderful, singular without opposite or precedent.

According to DiMaggio, Hargittai, Neuman, \& Robinson (2001) cited in Siah, Bansal, \& Pang (2010) the Internet is the "electronic network of networks that links people and information through computers and other digital devices allowing person-to-person communication and information retrieval." (p. 35).

The world has emerged to a point where new communications systems foster participatory democracy giving all citizens access to an infinite range of audio-visual content. These same over whelming perfections were notable features of earlier moments of culture and technological transition-the advent of the printing press, the development of still photography, the mass media of the $19^{\text {th }}$ century, the telegraph, the telephone, the motion picture and broadcast television (David, 2005).

Chaffee \& Metzger (2001) cited in Baran \& Davis (2006) argue that new media are bringing an end to mass communication and fundamentally altering how media will be structured, used, and conceptualized in the twenty-first century. Converse to Jenkins (2006), on the ongoing discuss on media convergence, arguments against "new media bringing an end to mass communication" have shedlight on the probable unintended consequences of convergence (Hamsley, Jacobson, Gruzd, \& Mai, 2018). They continue to postulate that while "all media will converge; the problem is simply to predict which media conglomerate or which specific delivery system will emerge triumphant" (David, 2005: p. 3).

New media technologies, new linkages and alliances across older media are generating profound changes in our political, social and aesthetic experiences (David, 2005; Eko, 2014). ICTs have enabled some African countries to be globally competitive and made Africa a continent where all types of ICTs have their place-from the "Tam Tam to Internet" (Lagmia, 2010; Ras-Work, 1998; Ngwainmbi, 1995; van Buisbergen, 2004; Nyamnjoh, 2005). Politically speaking, new technologies have facilitated communication and networking in ways that threaten erosion of monolithic state control of information and communication (Bourgault, 1995; Leslie, 2002). Proponents and enthusiast of the Internet such as former US Vice-President $\mathrm{Al}$ Gore, see it as "the essential prerequisite to sustainable development" (Hamelink, 1996: p. 19). In the US, for example, the Internet-e-mail-has enhanced and accelerated citizen participation in politics in elections (Grossman, 1994). In Africa, the Internet, once fully developed and widely installed, could indeed offer Africans many avenues to address current predicaments and promote good governance (Leslie, 2002). As Becker (1996) points out, far from being merely "just a step towards the information superhighway" (p. 10), the Internet is also the hope of many NGOs worldwide, scientists, critical journalists of alternative movements and counter movements, who wish to avail themselves of an independent, inexpensive, non-state-controlled, open communication network. Just like the term Information Superhighway 
denotes, it is a highway which has been widened and improved upon to become super (Nyamnjoh, 2005), with a literally unbounded content (Chaffee \& Metzger, 2001). New forms of communication technologies are fostering possibilities of disillusioned, impoverished and disempowered Africans, to be active and equal participants in the global conversations or the global republic of technology. Like other anti-neoliberal forces in the world, African activists have taken advantage of the new ICTs to mobilize and strategize against the multinational corporations and their yielding access to the resources and protection of African governments (Nyamnjoh, 2005). The efficacy of Internet use in Africa so far in political issues can be seen in what commentators have described as a "Facebook victory" and a "Twitter revolution", following the pivotal role the Internet played in the ousting of former Tunisian president, Zine al-Abibine Ben Ali in 2011, after 23 years in power of a regime widely described as intolerant and dictatorial. The Tunisian uprising inspired waves of unrest across the Middle East and North Africa. In next door Egypt, the long-term president Hosni Mubarak experienced a similar fate which culminated in an end to his over 30 years in power. The spillover effects also crossed over to bear pressure on the Libyan president Col. Muammar Kaddafi, who was later assassinated.

The story is similar in other parts of the world. For instance, the new media was very instrumental in the Philippines January 2001civilian-backed coupd'et at which saw the over-throw of President Joseph Estrada. The people believed in the power of communication technologies to transmit messages at a distance and in their own ability to possess that power. They achieved this through calls, text messages and the "crowd" (Chun \& Thomas, 2006). In the USA, in the 1994 congressional mid-term elections, "an-online political activist" from California was quoted as saying: "I think that by 1996 , we will begin to see some number of campaigns either won or lost because campaign operations either used or failed to use network communications and organizations" (International Herald Tribune, November 9, 1994 in Hugh et al. (1999). This has become true in recent times. The 2008 presidential elections in the USA were won by Barrack Obama largely because of his use of the Internet.

\section{Theoretical Perspective}

1) Uses and Gratification theory propounded by Jay Blumber and Elihu Katz in the 1970s seeks to explain the uses and functions of the media for individuals, groups and society in general. By extension, the theory has as core statements: the discovery of underlying motives for individuals' media use and identifying the positive and negative consequences of media use by individuals. It also explains the high use of the media that satisfies the needs and aspirations of people over other media. In the context of this study, the theory has been explored on the bases of the choice-use of the Internet as a medium for the dissemination of information by political parties in Cameroon. It has also been examined in the light of people who go to the Internet to get informed and to participate in political discussions. 
2) Agenda Setting theory of McCombs \& Shaw (1972) has been explored in this study with the aim of knowing what sought of agenda political parties set using modern communication technologies, which probably was not possible before this time. And as Cohen (1963) in McCombs \& Shaw (1972),would put it, the press may not be successful much of the time in telling people what to think, but it is stunningly successful in telling its readers what to think about. The Agenda Setting theory therefore, seems quite appropriate to enhance understanding of the pervasive role of the media, notably on political communication systems.

\section{Methodology}

The research approach was quantitative. Data was collected through mix research methods (survey and content analysis). The survey method was used to sample opinions (Eribo \& Tanjong, 2002; Ndue, 2017) on the Internet and political participation in Cameroon and on the other hand, content analysis was employed to study content of websites, blogs, other Internet posts. 100 respondents participated in the survey (with a random selection of 50SDF and CPDM supporters and 50 Political Science and Journalism and Mass communication students in the University of Buea). The study was limited to the first 7 months before the 2011 presidential elections. Content on the selected websites (SDF and CPDM parties) was checked thrice: January, April and July 2011. This was in order to monitor the use of these sites as the country prepared for the polls. For the content analysis, the researchers randomly choose the months of January and July to study progress on web content as the 2011 presidential elections drew near. Buea in the South west region of Cameroon was chosen as scope because it is a cosmopolitan and politically active city that represents a true picture of the political diversity of the country. It is host to one of SDF's most influential secretariats in the country and also the regional seat of the CPDM party for West Cameroon. As a university, academic and political hub, Buea is laden, comparatively, with Internet connectivity. The University of Buea has been characterized by a series of riots, particularly the 2006 strikes and 2011 upheavals. This made both students and inhabitants of the town well suited to participate in this study.

The questionnaire for the survey tested respondent knowledge and use of new media while correlating respondent relationship between the Internet and political communication. The data sheet for content analysis checked on party use of the Internet for their political propaganda. The survey, through questions, made use of individual responses of respondents, while the content analysis inferred meaning from words, phrases, sentences, paragraphs and pictures on the different online platforms. The analysis did not take cognizance of the frequency of the use but more, on whether or not they are used, as inferential data.

Survey data was collected from political supporters targeted at party secretariats (SDF in Bonduma and CPDM in Buea Town). Some events like the meeting organized by the Mayor of the Buea Council, on $10^{\text {th }}$ July, 2011 in Buea and cel- 
ebrations of the SDF chairman's birthday were also exploited. Data from the University of Buea was collected through the targeting of class sessions of Political Science and Journalism and Mass Communication students and lecturers. The data was processed and analyzed with the Statistical Package for Social Scientists (SPSS version 17). Uses of the Internet for instance which is one of the two main constructs of the study was tested with three direct questions on the questionnaire. The second construct of the study-effects of Internet use, was tested directly with four questions and indirectly with two questions in the instrument.

\section{Results and Discussions}

RQ1: What are the uses of the Internet by political parties in Cameroon?

\subsection{Uses of the Internet by Political Parties}

H1. Political parties use the Internet for activism/oppositional politics

The findings reveal that the Internet is used most as a support mobilization tool (43\%). This ties up with findings from content analysis done on the SDF and CPDM party official websites and weblogs, as shown in Table 1.

An overview of web content of the political parties analyzed in two different time periods (Table 1) shows partisan (things in support of the party) content. The SDF website content, for instance, greatly increased from $60 \%$ as of January $5^{\text {th }}$ to $90 \%$ as of July $23^{\text {rd }}, 2011$. This follows same for the CPDM. As the 2011 presidential elections closed in, competing parties were putting up the best strategies/ messages to keep supporters glued to the end. This is very evident with a complete change in their appearances and functioning of their websites. Besides the support mobilization factor (Table 2), political parties also used the Internet to study western democracies (26\%) as well as to set political discussions (18\%). On setting of political discussions, the SDF website for example (as of July, $23^{\text {rd }}$ 2011) provided a widget that displayed options for people to debate and contribute ideas on topical issues like the economy and defense. This same scenario obtains for the CPDM website.

Moreover, $8 \%$ of the respondents in the survey attest to the fact that political parties in Cameroon use the Internet to incite riots. The website for one of the

Table 1. Web content on party activism/oppositional politics.

\begin{tabular}{|c|c|c|c|c|c|}
\hline \multirow{3}{*}{\multicolumn{2}{|c|}{ Political party/Date accessed }} & \multicolumn{4}{|c|}{ Activism/ Oppositional politics } \\
\hline & & \multicolumn{2}{|c|}{ Partisan (\%) } & \multicolumn{2}{|c|}{ Strike/Revolt inciting (\%) } \\
\hline & & Official website & Other sites & Official website & Other sites \\
\hline \multirow{2}{*}{ SDF } & $05 / 01 / 2011$ & 60 & 20 & 30 & 30 \\
\hline & $23 / 07 / 2011$ & 90 & 40 & 10 & 30 \\
\hline \multirow{2}{*}{ CPDM } & $05 / 01 / 2011$ & 70 & 10 & - & - \\
\hline & $23 / 07 / 2011$ & 90.5 & 10 & - & - \\
\hline
\end{tabular}


Table 2. Uses political parties make of the Internet.

\begin{tabular}{ccc}
\hline Internet Use & Frequency & Percentage \\
\hline Mobilizing support & 43 & 43 \\
Study Western democracy & 26 & 26 \\
Setting political discussions & 18 & 18 \\
Inciting riots & 8 & 8 \\
No response & 5 & 5 \\
Total & 100 & 100 \\
\hline
\end{tabular}

contenders, Kah Walla, (accessed on $5^{\text {th }}$ January and February $22^{\text {nd }}, 2011$ ), was used to call on Cameroonians to take to the streets in protest against the Biya regime (incumbent) and the fight for "true democracy". The Chairman of the SDF party, John FruNdi, also talked of possible riots after his first meeting with the Head of State on the need to reform the election commission before the presidential polls. He said: "I requested that the president reform the electoral commission before next year's election. If this is not done, the SDF is going to organise a series of demonstrations across the country" (Musa, 2010).

Talking of the use of the Internet for oppositional politics, analysis of the CPDM official website of $5^{\text {th }}$ January 2011 and $23^{\text {rd }}$ July 2011 also presents two scenarios. The first presents an elaborate write-up by Prof. Jacques Fame Ndongo (CPDM Communication Secretary) titled: "Aquand le véritabledébat d'idées?" In which he completely debases the top oppositions to Biya's government (past and present) referring to them as arsonists. This vicious cycle of oppositional politics is seen again in the March 21, 2011 speech of the Secretary General of the CPDM central committee, Rene Emmanuel Sadi on the occasion of a preparatory meeting for celebrations marking the party's' 26th birthday. He called on party militants to be aware of the "methodically, scientifically and systematic antics of the radical opposition to our regime". These are just few examples in Cameroon of political parties' use of the Internet for activism and oppositional politics.

\section{RQ2. What are the effects of Internet Use by Political Parties?}

\subsection{Effects of Internet Use}

H2. The Internet enhances political participation in Cameroon

Thanks to the Internet, Cameroonians are able to actively participate in discussions on topical issues in the country. According to the findings, $36 \%$ of respondents agree to the Internet enhancing political participation in Cameroon. This is however, followed by $24 \%$ who are lost in the interactive power of the Internet. The findings show a negative skew in the response. This to say, that the response rate increases more to a disagreement in the Internet enhancing political participation. We can better understand the reasons for this by looking at medium of preference alongside reasons for choice use, as shown on Table 3. 
Table 3. Audience preference of medium.

\begin{tabular}{|c|c|c|c|c|c|c|c|}
\hline \multirow{2}{*}{ Reasons } & \multicolumn{6}{|c|}{ Medium } & \multirow{2}{*}{ Total } \\
\hline & Internet & Phone & Radio & Newspaper & TV & Rallies & \\
\hline Wider audience & 1 & 5 & 15 & 4 & 5 & & 30 \\
\hline Visual effects & - & - & - & 1 & 17 & - & 18 \\
\hline $\begin{array}{l}\text { Still to adopt newness } \\
\text { (Internet) }\end{array}$ & - & - & 2 & - & - & - & 2 \\
\hline Update on daily events & - & - & - & 7 & - & - & 7 \\
\hline $\begin{array}{l}\text { Easiest means of } \\
\text { communication }\end{array}$ & - & 1 & - & - & - & - & 1 \\
\hline Affordable & - & 3 & 15 & - & - & 1 & 19 \\
\hline Direct interaction & 3 & 1 & - & - & - & 12 & 16 \\
\hline $\begin{array}{l}\text { Loaded with } \\
\text { information }\end{array}$ & 4 & 1 & - & 2 & - & - & 7 \\
\hline Total & 8 & 11 & 32 & 14 & 22 & 13 & 100 \\
\hline
\end{tabular}

Radio (32\%) stands as the best medium to communicate political issues as revealed on the Table 3 above. The reasons advanced for this by respondents is that radio, which is more affordable than the other mediums, has both a wide urban and rural listenership. This is closely followed by the television (22\%) which pulls its following thanks to its image capacity. Further findings reveal that the Internet (8\%), in spite of its interactive and "search-ability" qualities, ranks last.

Figure 1 illustrates participation in online discussion vis-à-vis the sites used. It should be noted here that the categories (e.g. Facebook, Twitter, etc) are independent on a total of 100 respondents. Facebook (53\%) is the most used site for discussions by respondents and comments on the Internet. Next to this are Yahoo groups with a $34 \%$ response rate, Chat groups $(20 \%)$ and twitter $(7 \%)$, respectively. It is true that the Internet has increased political participation in Cameroon through the use of social media and other Internet applications like the Weblogs. A critical look into the content of Cameroonian political blogs, show cases of great participation in the form of comments and views on issues of concern. In Scribbles from the Den by Dibussi (2011), as accessed on July $23^{\text {rd }}$, 2011, for instance, stories on the February $23^{\text {rd }}$ riots of Mrs. Kah Walla and her Cameroon Obosso political party (now CPP) still top the maximum post list with over 22 comments.

H3. Internet use by political parties in Cameroon has ostracized the rural masses from active political involvement.

Table 4 reveals that rural masses in Cameroon have been ostracized from active political involvement as $70 \%$ of the respondents say such newness in political communication and interactivity is highly possible in the urban areas, which are more exposed to the facility. Other reasons advanced to this divide include financial constraints and the absence of electricity in most rural areas. The 


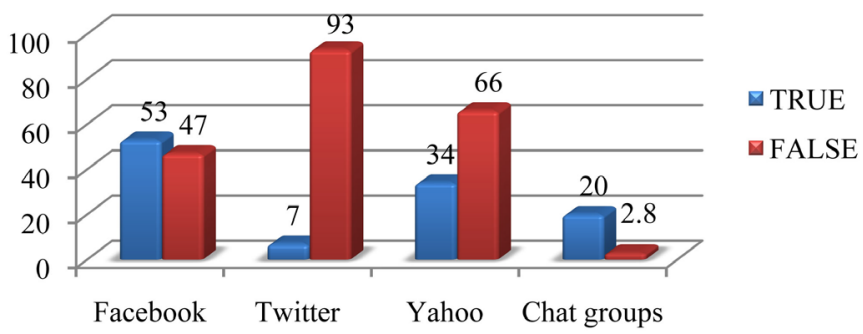

Figure 1. Online participation: Sites used for discussions.

Table 4. Area and reason for most effective Internet communication in cameroon.

\begin{tabular}{ccccc}
\hline \multirow{2}{*}{ Reasons } & \multicolumn{2}{c}{ Internet communication is Most effective in } & \multirow{2}{*}{ Total } \\
\cline { 2 - 4 } & Urban & Rural & No response & \\
\hline $\begin{array}{c}\text { Exposure } \\
\text { Accessibility \& Connectivity) }\end{array}$ & 70 & 3 & 0 & 73 \\
Poverty/lack services & 4 & 4 & 0 & 8 \\
Presence of electricity & 7 & 0 & 0 & 7 \\
No response & 1 & 1 & 10 & 12 \\
Total & 82 & 8 & 10 & 100 \\
\hline
\end{tabular}

effects of the Internet on the country's political heritage; moving from rallies, newspapers, radio and TV to the Internet (converging spot), leaves Cameroonians with no choice but to say that the Internet divides the country's political supporters to a great extent (43\%). See Figure 2.

H4. Internet use has increased freedom of speech and pluralized political ideas in Cameroon.

The Internet has a positive effect on freedom of speech and the pluralization of political ideas in Cameroon (Table 5). Reading from the measures of central tendency, most respondents (34\%) at a mode/median values of 2 , say the Internet has impacted these freedoms a great deal. The arithmetic means (2.4) show that the response rate increases to the positive. This is further corroborated by the degree of skewness (2.078). Thus, we can say with certainty that a $2 / 3$ majority of the respondents say the Internet is fostering freedom of speech and ideas in Cameroon.

These revelations further tie with findings on the February $23^{\text {rd }}$ attempted political riots in Cameroon. When respondents were asked where they got to know of the planned riots, before and after the event, the Internet (34\%) stood as the primary source. See Figure 3.

A critical look at some Cameroonian bloggers revealed that over $70 \%$ of their content is on political discussions, views and takes. This makes reference to prominent blogs like Dibussi's Scribbles from the Den, Ngwane (Ngwane, 2011) of Mwalimu George Ngwane, My Cameroon file, amongst others. In these blogs are found strong views and comments on "Law N²011/013 of 13 July 2011: 


\section{Extent of Political divide}

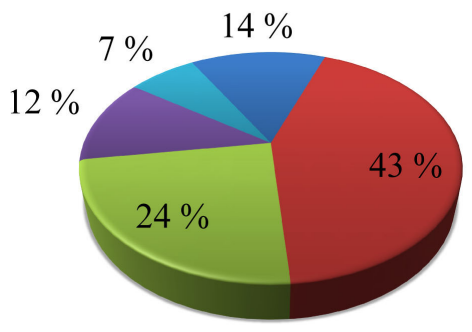

$\square$ Very great extent

$\square$ Great extent

$\square$ Little extent

$\square$ Very little extent

$\square$ No response

Figure 2. Extent to which the Internet divides the country's political supporters.

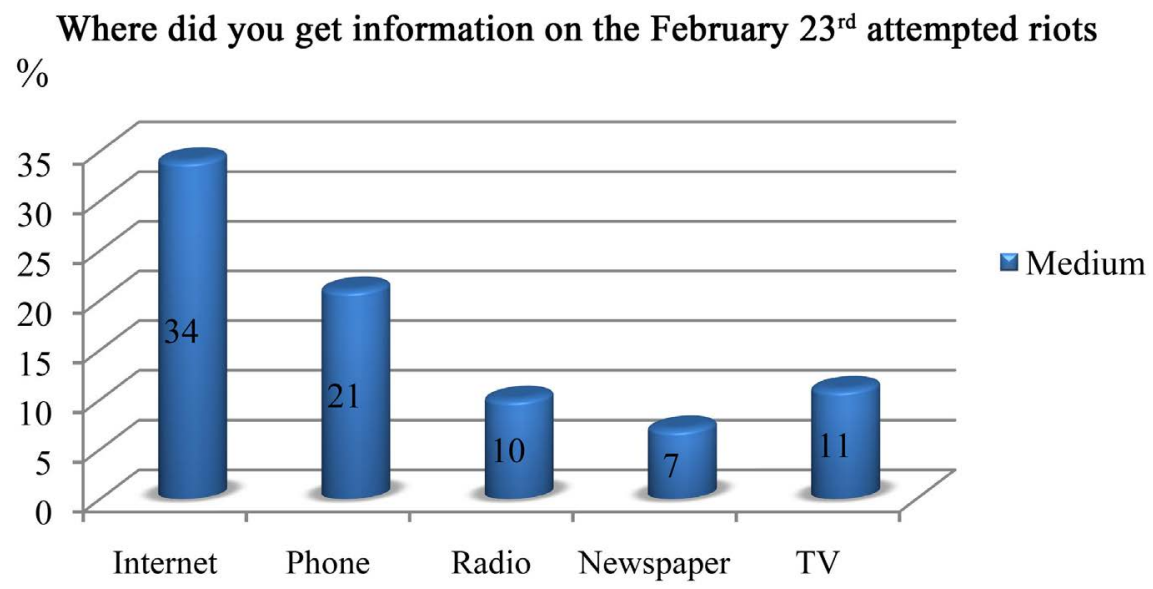

Figure 3. Sources of anti-government and pro-riots information.

Table 5. Degree of freedom of speech and diversified political ideas.

\begin{tabular}{ccccc}
\hline Degree of impact & Frequency & Percentage & Measures of central tendency \\
\hline A very great deal & 28 & 28 & & \\
A great deal & 34 & 34 & Mean & 2.4 \\
Quite a bit & 25 & 25 & Median & 2 \\
Some extent & 4 & 4 & Mode & 2 \\
Little/None & 7 & 7 & Skewness & 2.078 \\
No response & 2 & 2 & Std. Error of skewness & 0.241 \\
Total & 100 & 100 & & \\
\hline
\end{tabular}

Relating to Voting by Cameroonian Citizens”; Memory Lane (May 16-17, 1991): Opposition Parties Launch "Operation Ghost Town"; "Cameroon Bans Twitter Via SMS to Insulate Itself Against Digital Activists"; Kah Walla In Her Own Words: "We Now Have Extreme Clarity on the Absolute Need for Change"; amongst others. Thus, with these, it is safe to conclude that the Internet has increased freedom of speech and pluralized political ideas in Cameroon. The freedom to say things usually comes with getting people to take actions as a result of what they have read, heard and/or seen. According to respondents, the messages they read on the Internet has a toll on probable behavior (see Figure 4). 
How would you describe messages on the Internet and Possible action? $\%$

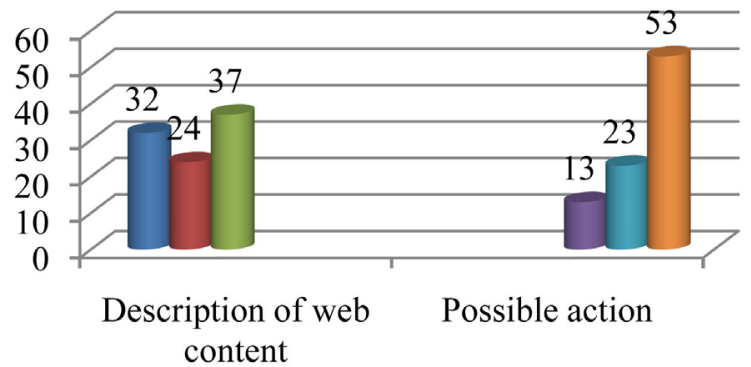

Revolt inciting

- Partisan

vote oriented

Strike

Vote

Figure 4. Effects of Internet on political action.

In the category on description of web content, $37 \%$ of respondents say the messages they read are vote-oriented. $32 \%$ say they are revolt-inciting and $24 \%$ say they are partisan. Looking at the other category on possible actions as a result of these massages, more than half the respondents (53\%) say these messages call on political participation. This is seconded by a rather small respondent rate (23\%) that is more specific on their action to vote and finally by a dismal $13 \%$ of respondents who are ignited to strike.

\subsection{Other Vital Findings}

Probing to investigate on respondents' knowledge on the Internet, $64 \%$ of the respondents' were positive to what the Internet is. $7 \%$ of respondents said they know what the Internet is but found it difficult to back their knowledge with examples. In all, $10 \%$ of the respondents do not know what the Internet and new media are, though they use them. The study also revealed that, most people (71\%) use the Internet for socialization rather than for specific reasons like keeping up-to-date on political issues (29\%).

On demographic distribution, 37 males and 26 females constituted respondents for the study. With regards to participating in online discussions, more males (42\%) as opposed to (35\%) females are active participants. This is reflective of a country whose political scene is flooded with men and a handful of women. Also, the study revealed that $52 \%$ of the respondents belong to a political party (50 CPDM/SDF, plus 2 from academics) while $48 \%$ of them are mere political fans and some form of supporters.

\section{Conclusion}

Borrowing from Coombs \& Craig (1998), the phenomenal growth of the Internet has increased political participation in Cameroon (51\%, majority). $43 \%$ respondents attest to political parties' use of the Internet as a tool to mobilize support (political campaigns); a situation which intensified during the 2018 presidential elections (Ngange, 2019). Both the SDF and CPDM party websites used as case studies have widgets calling on people to either vote, join the party, support the party financially or materially or participate in debates and discussions 
on salient issues like the economy, defense, education and health. Also, political parties in Cameroon do not only make use of their official websites activities but use other social networking sites like Facebook, Youtube and Twitter. Despite this, $32 \%$ of respondents hold that radio is still the best communication medium for the Cameroonian people, owning to its urban/rural audience reach and more affordable nature. Television (22\%) for its visual capacity and newspapers (14\%) for its everyday updates and possibilities for prolonged reading come in as next best choices. The Internet comes last in this roll with $8 \%$ response rate after rallies (13\%) and mobile phones (11\%). Though the Internet is proven to be a great mobilization tool, the effect has not yet had a welded grip on the country's political landscape (averagely effective-50\% - 60\%). This may account for one of the reasons why the February $23^{\text {rd }} 2011$ attempted riots in Cameroon was ineffective.

The Internet may be good for a number of reasons, but one for which it is not in Cameroon is that it has ostracized the country's political supporters. Many who use the Internet for whatsoever reasons are found in cities and towns, which uses are made possible thanks to the availability of better internet connectivity and electricity supply. The inadequacies of the Internet are heavily linked to the countries epileptic power supply system in urban areas and gross absence in rural areas (Ngange, Enow, \& Tanjong, 2012). But the immediate cause for low Internet adoptability and usability is the high cost associated to it (Mbarika \& Mbarika, 2006).

In relations to concerns about whether the CPDM website is used to canvas support for the party's "natural candidate" (Cameroon calling, 2010), President Paul Biya, against the 2011 presidential run-offs, findings to this effect were positive as are vividly seen in the speech presented by the party's central committee Secretary General, Rene Sadi on the occasion of the party's $26^{\text {th }}$ birthday celebrations in Yaoundé and a write-up by Professor Jacques Fame Ndongo amongst others. The use of the Internet to canvas for support is not employed by just the CPDM party. The SDF and Cameroon Obosso (now CPP) parties also do same.

Conclusively, the uses and gratification theory (Jay Blumber and Elihu Katz, 1974) has shown relevance in this study. Respondents go to the Internet for various reasons: some to connect with friends and family (71\%) and others to update their knowledge on political issues in the country (26\%). The study also sheds light on the uses and functions of the Internet by political parties. Political parties largely use the internet to mobilize support for their course (43\%).This internet engagement is on the rise. According to France24 (2018) social media played a key role in the 2018 presidential elections in Cameroon as almost all of the nine presidential candidates had dedicated online presence. Also, political parties do use the internet as a resource tool to study western democracies (26\%). On the low, the internet is used by political parties in Cameroon to incite riots $(8 \%)$. Using the internet to propagate protests has become a near normal since the 2018 Presidential elections in Cameroon. Following waves of unrest in Cameroon, orchestrated by the Cameroon Renaissance Movement (CRM) of Maurice Kamto (one of the presidential candidates) and a coalition of other po- 
litical parties, information of these protests was widely circulated on the internet, with corresponding effects and waves of protests on January 10, 2019 at Cameroon's embassies in France, Belgium and Germany. The Great white march of June1, 2019 of the CRM party in some major towns in Cameroon like Yaoundé, Douala, Nkongsamba, Bafoussam and Bangangte is also evidence of the power of new media as a tool to mobilize people-in this case to protest.

Furthermore, the Agenda Setting theory (McCombs \& Shaw, 1960) comes in apt as political parties use the Internet to set public agendas. Thanks to the Internet, political parties have been able to carry out propaganda widely (62\%). They post blunt calls for violent demonstration messages on the Internet. All of these culminate to say that through this modern, almost censor-free communication technology-Internet (Jenkins, 2006; Chun \& Thomas, 2006), political parties and supporters are able to say things which before now were impossible with the systematically highly censored newspaper, radio and television media in the country (Ewumbue, 1992). But, as Nyamnjoh (2005) said, the internet and other applications of the social media can be effective in guaranteeing major Facebook victories and Twitter revolutions, without absolute corresponding changes in real life.

In a time when the internet is taking center stage in political marketing around the world, (including Cameroon), the importance of knowledge on the relationship between the mass media (internet) and political propaganda is expedient. Stakeholders (politicians and citizens) must master the dynamics of this new form of communication to be able to generate considerable influence which should not translate in anarchy. Internet users should therefore, avoid unnecessary propaganda. Examples of internet propaganda from the Arab Spring to the current Cameroon Anglophone Crises warrant a rethink of the uses and effects of the internet by political actors.

\section{Conflicts of Interest}

The authors declare no conflicts of interest regarding the publication of this paper.

\section{References}

Baran, J., \& Davis, K. (2006). Mass Communication Theory: Foundations, Ferment, and Future (4th ed.). Belmont, CA: Thomson Wadsworth.

Becker, J. (1996). The Internet, Structural Violence and Non-Communication. Media Development, 43, 10-12.

Berinsky, J. A. (2004). Silent Voices: Opinion Poll and Political Representation in America. Princeton, NJ: Princeton University Press. http://press.princeton.edu/titles/7757.html

Bourgault, L. M. (1995). Mass Media in Sub-Saharan Africa. Bloomington, IN: Indiana University Press.

Cameroon People's Democratic Movement (2011). http://www.rdpcpdm.cm

Chaffee, S. H., \& Metzger, M. J. (2001). The End of Mass Communication? Mass Com- 
munication and Society, 4, 365-379. https://doi.org/10.1207/S15327825MCS0404_3

Chun, W., \& Thomas, K. (2006). New Media, Old Media: A History and Theory Reader. New York: Routledge Taylor \& Francis Group.

Coombs, W., \& Craig, W. (1998). Mediated Political Communication, the Internet, and the New Knowledge Elites: Prospects and Portents. Telematics and Informatics, 15, 203-217. https://doi.org/10.1016/S0736-5853(98)00013-6

David, H. (2005). Communication Theory: Media, Technology and Society. London: Sage.

Davis, M. D. (1995). Illusions and Ambiguities in the Telemedia Environment: An Exploration of the Transformation of Social Roles. Journal of Broadcasting \& Electronic Media, 39, 517-554. https://doi.org/10.1080/08838159509364323

http://heinonline.org/HOL/LandingPage?collection=journals\&handle=hein.journals/jb em39\&div=48\&id=\&page

Dibussi, T. (2011). Scribbles from the Den. http://www.dibussi.com/2011/07

DiMaggio, P., Hargittai, E., Neuman, W., \& Robinson, J. P. (2001). Social Implications of the Internet. Annual Review of Sociology, 27, 307-336.

https://doi.org/10.1146/annurev.soc.27.1.307

Eko, L. S. (2014). New Media, Old Regimes: Case Studies in Comparative Communication Law and Policy. Lanham, MD: Lexington Books.

Eribo, F., \& Tanjong, E. (2002). Journalism and Mass Communication in Africa: Cameroon. Lanham, MD: Lexington Books.

Ewumbue, M. C. (1992). The Right to Inform and the 1990 Press Law in Cameroon. Africa Media Review, 6, 19-29.

France24 (2018). In Cameroon, Social Media Plays Key Role in Vote Campaign. http://www.france24.com

García, L. Ó. (2006). E-Activism: New Media and Political Participation in Europe. CONfines.

Graber, D. A. (1981). Political Languages. In D. Nimmo, \& K. Sanders (Eds.), Handbook of Political Communication (pp. 195-224). Beverly Hills, CA: Sage.

Grossman, L. K. (1994). Reflections on Life along the Electronic Superhighway. Media Studies Journal, 8, 27-39.

Gwellem, J. F. (1996). Fru Ndi and the SDF Revolution. Bamenda: Unique Printers.

Hamelink, C. J. (1996). Globalisation and Human Dignity: The Case of the Information Superhighway. Media Development, 43, 18-21.

Hamsley, J., Jacobson, J., Gruzd, A., \& Mai, P. (2018). Social Media for Social Good or Evil: An Introduction. Social Media + Society, 4, 1-5. https://doi.org/10.1177/2056305118786719

Herbst, S. (1994). Politics at the Margin: Historical Studies of Public Expression outside the Mainstream. Cambridge: Cambridge University Press.

Hugh, M., \& O’Sullivan, T. (1999). The Media Reader, Continuity and Transformation. London: Sage.

Jeffres, L. (1986). Mass Media: Process and Effects. Long Grove, IL: Waveland Press.

Jenkins, H. (2006). Convergence Culture. New York: New York University Press.

Karan, K., Gimeno, J., \& Tandoc, E. (2009). The Internet and Mobile Technologies in Election Campaigns: The Gabriela Women's Party during the 2007 Philippine Elections. Information Technology \& Politics, 6, 326-339.

https://doi.org/10.1080/19331680903047420 
Lagmia, K. (2010). The Role of Online Media Technology and Democratic Discourse in Cameroon: A Case Study of the Post and Cameroon Tribune. In C. U. Nwokeafor, \& K. Langmia (Eds.), Media and Technology in Emerging African Democracies (pp. 65-82). Lanham, MD: University Press of America.

Leslie, M. (2002). The Internet and Democratization. In G. Hyden, M. Leslie, \& F. F. Ogundimu (Eds.), Media and Democracy in Africa (pp. 107-128). Uppsala: The Nordic Africa Institute.

Maarek, P. J. (1995). Political Marketing and Communication. London: John Libbey \& Company.

Mbarika, V. W. A., \& Mbarika, I. (2006). Africa Calling: Burgeoning Wireless Networks Connect Africans to the World and Each Other. IEEE Spectrum, 43, 56-60. https://doi.org/10.1109/MSPEC.2006.1628825 https://ieeexplore.ieee.org/document/1628825

McCombs, M. E., \& Shaw, D. L. (1972). The Agenda-Setting Function of Mass Media. Public Opinion Quarterly, 36, 176-187. https://doi.org/10.1086/267990

McLeod, J., Pan, Z., \& Rucinsk, D. (1995). Levels of Analysis in Public Opinion Research. In T. Glasser, \& C. T. Salmon (Eds.), Public Opinion and the Communication of Consent (pp. 55-85). London: Guilford Press.

Miller, C. C. (2008). How Obama's Internet Campaign Changed Politics. The New York Times. http://www.bits.blogs.nytimes.com

Muluh, H. (2002). History of Mass Communication in Cameroon.

Musa, T. (2010). Cameroon Opposition Head Threatens Poll Protest. https://www.reuters.com/article/ozatp-cameroon-opposition-20101211-idAFJOE6BA0 0T20101211

Ndue, P. N. (2017). Research Methodology: Theory and Practice. A Practical Guide for Successful Development and Presentation of Academic Research. Buea: Beraka.

Ngange, K. L. (2019). Social Media Use in the 2018 Presidential Elections in Cameroon.

Ngange, K. L., Enow, B., \& Tanjong, E. (2012). The Challenges of Power Generation (Electricity) on ICT Penetration in Cameroon and the Way Forward. African Journal of Contemporary Issues, 12, 185-197.

Ngwainmbi, K. E. (1995). Communication Efficiency and Rural Development in Africa. Lanham, MD: Rowman \& Littlefield.

Ngwane, G. (2011). Ngwane. http://www.gngwane.com/2011/03/cameroon-2011.html

Nimmo, D. (1978). Political Communication and Public Opinion in America. Santa Monica, CA: Goodyear Company.

Norris, P. (2001). Political Communication. In N. J. Smelser, \& P. B. Baltes (Eds.), International Encyclopedia of the Social \& Behavioral Sciences (pp. 11631-1640). Amsterdam: Elsevier. https://doi.org/10.1016/B0-08-043076-7/04364-3

Nwokeafor, C., \& Langmia, K. (2010). Media and Technology in Emerging African Democracies. Lanham, MD: University Press of America.

Nyamnjoh, F. F. (2005). Africa's Media: Democracy \& the Politics of Belonging. London: Zeb Books.

Ras-Work, T. (1998). Tam Tam to Internet. Johannesburg: Mafube.

Rotunda, R. (1986). The Politics of Language: Liberalism as Word and Symbol. Iowa City, IA: University of Iowa Press.

Siah, M., Bansal, N., \& Pang, A. (2010). New Media: A New Medium in Escalating Crisis? Corporate Communications: An International Journal, 15, 143-155.

https://doi.org/10.1108/13563281011037919 
Social Democratic Front (2011). http://www.mysdf.org

Soriano, M. T. (2013). Internet as a Driver of Political Change: Cyber-Pessimists and Cyber-Optimists. Revista del Instituto Español de Estudios Estratégicos, 1, 332-352.

Tanjong, E. (2006). Africa in International Communication. Limbe: Design House.

Thorburn, D., \& Jenkins, H. (2003). Democracy and New Media. London, Cambridge, CA: The MIT Press. https://doi.org/10.7551/mitpress/2328.001.0001

Tufte, T., Wildermuth, N., Hansen-Skovmoes, A., \& Mitullah, W. (2013). Speaking Up and Talking Back? Media, Empowerment and Civic Engagement among East and Southern African Youth. The International Clearinghouse on Children, Youth and Media Series, Sweden: Nordicom.

van Binsbergen, W. (2004). Can ICT Belong in Africa, or Is ICT Owned by the North Atlantic Region? In W. van Binsbergen, \& R. van Dijk (Eds.), Situating Globality: African Agency in the Appropriation of Global Culture (pp. 107-146). Leiden: Brill. 